\title{
The existence of Kendang Reog Art in Postmodernism
}

\author{
Wiga Nugraheni ${ }^{1}$ Kusnadi $^{2}$ Aida Roihanna Zuhro ${ }^{3}$
}

\author{
${ }^{123}$ Universitas Negeri Yogyakarta, Yogyakarta, Indonesia \\ *Corresponding author.Email: wiga.heni23@gmail.com,
}

\begin{abstract}
The postmodernism perspective in art can be identified from the emergence of new ideas in the field of art, in which there are no boundaries. One example of this can be seen in the shift in form and meaning of a traditional Javanese performance art named Reog Kendang. Reog Kendang, a folk art from the Tulungagung Regency that serves as one of the region's attractions, has experienced many developments from its original form. The traditional performance art initially had very particular rules, but has developed in its meaning and form of presentation over time as they are adjusted based on the demands and context of performance art. This paper aims to depict the form of Reog Kendang in the postmodern era and its existence using qualitative method and phenomenology approach. Data were collected through observations, interviews, and documentation, followed by an analysis involving data reduction, presentation, and drawing conclusion. The findings reveal that the development and existence of Reog Kendang can be seen from the change in the form of presentation and demands of the performance that allow the artists to make creative adjustments and innovations. As a result, the audience may enjoy and feel the result of the development which helps Reog Kendang to remain relevant in the postmodern era.
\end{abstract}

Keywords: Existence, Development, Reog Kendang

\section{INTRODUCTION}

Indonesia is an archipelago that has many islands and various ethnic groups, languages, customs, or cultures. The diversity of culture proves that Indonesia is a rich country in traditions. It is undeniable that regional culture is the main factor in the establishment of national culture. Therefore, all forms of regional culture will greatly influence the national culture, on the contrary those originating from regional culture will also affect regional or local culture. Culture has a very meaningful value, because it is not only creating the characteristics of an area but also becoming a symbol of the personality of a nation. Of the various forms of art, dance shows the aesthetics of the human organ movements that have beautiful rhythms and expressions. Dance has many kinds of arts, one of which is community art. In Tulungagung, East Java, it has a unique art, namely Reog Kendang Art. Traditional art that grows and develops in society for generations has elements of belief and the meaning of traditional interpretations in the community as the characteristics. If the art grows at the regional level, it belongs to the region. Like Reog Kendang in Tulungagung Regency, it is a traditional art developed in the community. In the beginning, there were not many people who knew this art either inside or outside the Tulungagung region. However, as time goes by, the art is experiencing an extraordinary development. The existence of the art began to be loved by all groups, ranging from children to adults.

The results of human works in the world have a variety of forms; of course, they always experience a change and development from time to time, because it is not possible for a human masterpiece to simply happen and stop right there. This super-modern era with sparkling cities and magnificent tall buildings attract artists to come and even participate in it.

In the world of performance arts, artists are struck by a dilemmatic position. On one side, the artists must have ideal ideas with their respective authorities to put them as the foundation of their creativity, so that imagination can create a piece of art which is truly pure and original. This means that the ideas are not the contributions from sponsors or other people, patronized by other parties, dictated by government institutions, or set in a context and so on. In life, human has rules which are usually called customs that create various types of culture that will become a characteristic of people in the area. The existing art grows in the community along with the socio-cultural development of the supporting community.

On the other hand, the current form and patterns of Reog Kendang Tulungagung have varied greatly, depending on the creativity of the artists. It is possible that someday it will develop from time to time in various forms and patterns of Reog Kendang Tulungagung. New forms of presentation emerge from year to year, which has increasingly developed from the simple form of Reog Kendang which is only performed by six male troopers, 
but now many women also join to dance. Simple movements have increasingly been developed by artists based on the market needs. In addition, the development of the variety of the musical instruments also varied, not only kendang dhodhog, kenong, gong, but also a number of musical instruments of balungan karawitan that complement and beautify the form of presentation.

Postmodernism is a situation where everything in this world becomes excessive in any context. People prefer to spend their money to lift up their prestige and popularity in the society view. Postmodernism [3], literally, consists of the word "post" which means period after "modern" (the modern era). Therefore, it can be concluded that postmodernism is a period after the modern era (era above the 1960s)

The shift in value of a work of art occurs from a variety of perspectives, from the emergence of contemporary art and various resembling arts. The term "art" which was once more sacred for most people has now become something normal. Art is only a symbol of an identification of something to make it look attractive. In line with this, art as an element of culture is seen not only as a creation in the form of objects, human products, but also as a symbol that says something about an object, so that it is confronted with the meaning [14].

In the view of postmodernism, that is what makes a polemic in the postmodern era, where works of art have started to run away from their sacred forms. Human can be more creative to express their ideas of creativity and free to think of art. Hence, there is a problem regarding the existence of the actual art in the postmodern era in order to be separated and known about which art has and gives no values.

Based on the background of the problems above, this study aims to describe the existence of the Reog Kendang art in the postmodern era. Is art only as a symbol of identity? does postmodern art have no value? or does ancient art have to change according to the today conditions?.

\section{RESEARCH METHOD}

In this research, the authors use a qualitative descriptive method with a phenomenological approach. Through the method, it is intended to understand a phenomenon that occurs in research subjects such as behavior, perception, and action holistically and descriptively in the form of words and language and in a natural context [12]. Philosophically, qualitative research is referred to phenomenology; we must return to objects with the opportunity to speak through phenomenological descriptions so that the nature of symptoms can be revealed [13]. The research instrument was the writers themselves. The authors refer to the basic form of research (descriptive research), in which this study describes both natural and unnatural phenomena. The data collection was conducted through observation, interviews, and documentation. Then, the data were analyzed in several steps in accordance with the three steps proposed by Miles and Huberman [9]; they are data reduction, data display, and conclusion drawing and verification.

\section{DISCUSSION}

\subsection{History of Reog Kendang Art}

Throughout the history of life, human can not be separated from art, because it has become one of the cultural elements created by people, which contain the value of beauty (aesthetics). [1] Art is all human actions that arise from feelings and have a beautiful function, so that the human soul can be encouraged. It is something attached to the existence of human life, and is part of seven aspects of culture. Also, art [56] is something complex that arises from ideas, expressions, values, norms, and rules in which activities and actions have patterns from humans in society and are usually real and shaped by human works.

Based on the definitions, art is one of the supporting elements or as a foundation for cultural reinforcement which means that one of the pillars is art. It can be concluded that art is an expression that arises from the human soul in its survival that shows a creative process without leaving the element of beauty, norms, and the culture that already exists and develops in the surrounding environment.

Kendang Reog art is included in the art in the form of folk dance. The form in dance is a unitary motion commonly referred to as motion motive. In dance performances, it is not only realized through the series of formed movements but also presented through overall system. The form is manifested in the system found in the supporting components of dance. The presentation in an art means that as a procedure, the process of presenting a work of art composed of various motives based on dance supporting elements must be present in a performance, because these supporting elements are very influential when viewed from aesthetic values in a show. To perform an aesthetical presentation in the process of making dance works, there are several supporting elements that must be considered, including movements, floor designs, accompaniment song, make up, costume, lighting, stage, venue, and dance property .

The origin of the story Reog Kendang Tulungagung [2] is considered as the tale of Kedirilaya warriors who accompanied the Queen Kilisuci's journey to Mount Kelud, symbolized by six dancers. Narrated in the dance art, it is showing how difficult the journey was and how heavy the burden carried was, until his body got stumbled; the road down was full of steep valleys and mountains. Arriving at the top of the mountain, the warriors surrounded the crater by looking inside, until the princess fell into it. On the other hand, the troops threw stones and burried her and this made Jathasura jump in to help the princess, but he also died buried in the crater. This was the sense of joy and victory that the warriors got after treated badly for the fulfillment of the desire to propose to the princess. 
Therefore, all the expressions and scenes are performed and then symbolized into expressive and beautiful dance movements, which are widely used in such movements such as simultaneous footsteps in various variations, body movements, shoulders, neck and head, accompanied by serious facial expressions, while both hands are busy playing dhodhog which is held and tied with a shawl crossed through the right shoulder. The left hand holds the dhodhog to give the desired rhythm, combined with dance moves in a tempo that varies from slow to quick. Those are the symbols expressed through various dance movements; it is accompanied by a monotonous magical gamelan music, with a shrill sound that produces melodies continuously; the audience is really amazed.

With a unit of 6 dancers, they can make movements in the form of configuration or floor pattern. For the floor pattern, there are no standard rules; it depends on the agreement of the artist and/or the art performer.

\subsection{Reog Kendang Art Existance}

Existence [8] comes from the word 'exist' which has the meaning of life, and 'ence' which means things, results, actions, conditions, and life, everything that exists. In the Indonesian Dictionary, it comes from the word 'present' which means visible and tangible. Thus, existence means the presence of something in life. It is a term that is often used in the fields of philosophy and psychology. In philosophy, existence is defined as the presence of everything, while in the field of psychology, existence is life and presence.

Existence is not rigid but flexible and experiences development or backwardness, depending on the ability of individuals to actualize their potential. The term 'existence' is analogous to 'verbs' and 'nouns'. It is a private property; there are no two identical individuals. Therefore, existence is a private property whose the presence cannot be compared to one another.

The art existence seems to be increasingly loved by all levels of community, especially among the artists. They have their own views or ideas to preserve Reog Kendang art, developing the art presentation and dance works until now. In fact, many artists have changed the standards of the art for the demands of the commercial world of performance arts. Existence in this case is not only seen by the quantity of the presentation form but also the quality. It can be said that the development of society traditional art is a result of the globalization influence [10].

However, those are not an important issue, instead the government and community are very supportive toward the development of the Reog Kendang art presentation, because the art existence is increasingly recognized and known by everyone. Even now the art has been known to people in areas outside Tulungagung Regency. This is very beneficial for the region in terms of preserving regional art.

\subsection{Development of Reog Kendang Art Presentation in Postmodernism}

Development is a creation, renewal, addition of a wealth of creativity without leaving the values of existing traditions [7]. Based on this understanding, it means that development is a process of re-creation by presenting new things that are more creative without leaving the values of existing traditions.

These changes, both past and present, are all recorded in the form of a piece of art. The results of human work in this world must always undergo changes and developments, because it is impossible for human work to happen as such and simply end. Of course, art works are created from the simplest form of work with simple materials, and from time to time the artwork will experience a process of development in accordance with its era.

Postmodernism was introduced into the fields of philosophy and science in the 1970 s by a philosopher Jean-Francois Lyotard. Thinking on science from the perspective of modernism as a big narration such as the existence of freedom, progress, and so on, according to him, is now experiencing the same problems such as the terms of religion, national nationality, and belief in excellence that occur in European countries, which are for the time being is not quite right [8]. Hence, postmodernism invites us not to immediately take it for granted to science; accepting the truth must be investigated and proven first. For Lyotard, the science of postmodernism is not merely an instrument of authority; it expands us to see different views, and strengthens our ability to tolerate an attitude that cannot be compared.

The emergence of postmodernism is inseparable from modernism, a word that has a meaning of an advanced era, all glittering that promises us to go to a time of changing world which is more advanced, established, and settled [8]. In terms of art knowledge, Lyotard radically rejects the meaning in every work of art. Art as philosophy does not have ties to the problems of meaning, identity, and truth. According to him, art has an energetic capacity, where the energy in art is the driving force and is not controlled by the reason of human consciousness [4]. Art in philosophical thinking, according to him, is seen not only as a meaningful representation, but also as a power that manifests itself. Understanding of art according to Lyotard is very unique, especially those associated with "beauty" or "beautiful". In his view, postmodernism is not only a kind of way of thinking, but rather leads to an open system and allows the art to open diversity that is not deterministic, diversity which contains a life that has its own rules without being controlled by human [6].

The sublime idea by Immanuel Kant about the aesthetics accepted by Lyotard in fact strengthens his belief in something expressed in art. This belief brings it in circumstances where there is never "outside" or "others". The difference between "modern" and "postmodern" for Lyotard only lies in the recognition of "unmanifested" and its appearance. Modern postmodern aesthetics has the 
same highly interesting appeal. Aesthetics in art and art itself cannot be bound together in one language system. Art also has its own appeal that is able to create phenomena. Therefore, art should not adjust to the conditions that should be, but it is able to follow its energetic power to achieve nobleness (sublime).

The shift from the value of art can be studied through various perspectives, from the emergence of contemporary and similar arts. An art is considered only as a limit of discourse. The term art is more easily used by people at this time, although it is still experiencing problems, which require that art has a spirit in it. A work of art can be used as a form of communication completely with the audience or connoisseurs of art, if they know the value or spirit that is in the work of art [13]. In connection with this, the artist creates his work with the meaning and interpretation of certain values. This is what creates warm conversations in the postmodern era, where the original or sacred form of art has begun to blur.

Like the Reog Kendang art, this was once very simple, with only 6 dancers in a team carrying dhodhog to be played and dancing like the style of royal warriors. Very monotonous movements and accompaniment are the characteristic of folk art. In postmodernism that has spread into various fields of knowledge, it can be termed as various forms of artwork back to the values previously forgotten in the modern era. However, due to flexibility, many people find it increasingly difficult to give values and find meaningful art, because basically every artist is creating art that is different from the others or unique. Therefore, in 2019, the Reog Kendang art has developed in terms of a form of presentation in this postmodern era.

Postmodernism has the opposite characteristics of those in its predecessor era, namely: emotions which are more emphasized than rationales, media rather than content, signs rather than meanings, plurality rather than singularity, possibility rather than certainty, games rather than seriousness, openness rather than concentration, local rather than universal, fictions rather than facts, aesthetics rather than ethics, and narrative rather than theoretical [4]. The essence of artistic value is more emphasized than the rationale itself. Openness is more emphasized, so from such circumstances it can be assumed that there is possibility of a very large opportunity for everyone to express art. Therefore, artists in Tulungagung have more freedom to be creative to develop and renew the Reog Kendang art, so that the art existence is increasingly recognized by all levels of society.

Sumardjo says[13] that good art provides experience, both emotional experiences or knowledge from the world. Thus, views in the postmodern era make people think more individualistically; therefore unique works of art appear and increasingly make art connoisseurs think of the true meanings of the art. Postmodern people emphasize beauty, not working directly in expressing ideas, but manifesting them in an experience of an art life which is the sincere satisfaction of beauty.

Openness is a characteristic of postmodern, which does not want high classical art to be placed above pop culture, but postmodernism is unique because it has reached ordinary people's class not only the elite class. Therefore, postmodernism has an impact on popular art (Reog Kendang) which eventually experiences novelty and development. This novelty as revealed [3], postmodernism characteristics highlight the concept of "de". This concept began to manifest itself by doing dehumanistic, destructuristic, and decentralized. The hope with this concept will produce novelty in the order that is considered appropriate. That is how the novelty can be seen in real life by postmodern artists.

Development and renewal in the form of presenting Reog Kendang art happen in the number of players and accompaniment. The performer or dancer, besides dancing, also acts as an instrument player. However, the instrument was not only played by dancers, but also performed by other pengrawit/players for a set of Javanese gamelan. The main instrument is called as dhodhog, which is a musical instrument similar to a drum. There are 6 types of dhodhog: (1) dhodhog kerep, (2) dhodhog arang, (3) dhodhog imbal I, (4) dhodhog imbal II, (5) dhodhog keplak, and (6) dhodhog trinthing. The number of Reog Kendang dancers is in accordance with the number of dhodhogs, which is 6 . How to use dhodhog is carried with a shawl that is placed on the right shoulder, so that the position is on the left hip. Nowadays, dhodhog is not only carried and hit; it has a double function as a dance property. The dhodhog is used for dancing, being lifted, played, and even put. In addition, the standard motion presented by the Reog Kendang art has also been updated and even changed, which initially had 10 standard movements that have meaning in each of its movements, namely (1)gerak baris,(2) gerak sundangan,(3)gerak andul, (4)gerak menthokan, (5)gerak gejoh bumi, (6)gerak ngongak sumur, (7)gerak midak kecik, (8)gerak lilingan, (9)gerak kejang, and (10) gerak kejang. The standard motion is very simple and repetitive with the same tempo. The renewal of motion is developed into a dance movement that was quite expressive, dynamic and energetic. The motive of the movement is presented in East Javanese style with varying tempos combined with a very attractive floor design; even the original meaning of the motion is no longer important, because the most important thing is the aesthetic movement.

In addition, the development can also be known from the shape, makeup, and costumes. Initially the makeup that was used in this art was simple, which only highlights the male troop's character. However, when the dance is performed by female warriors, the beauty and authority are pointed out. It can be clearly distinguished for dashing makeup (such as the addition of mustaches and beards) on male dancers and beautiful makeup for female dancers (emphasizing facial lines such as eyebrows, eyes with eyelashes, nose, blushed cheeks, and lips to highlight her character as a beautiful woman.

In terms of fashion, it used to be identically simple using the basic color of a black shirt and brightly colored attributes. The costume was long-sleeved black shirt, at the rear pinned a dagger as an additional accessory. A red or yellow attribute is attached to the sleeve to make it look contrasted with the basic color of the shirt. Also, they wore below knee black pants and used a long batik cloth (jarik) 
wrapped around the waist, and then on the front dangled down. A setagen (corset) is worn, and the outside part is decorated with red or yellow sampur (cloth). It is also completed with a black headband with iker-iker (edge of the hat) but it has a long cylindrical shape with a diameter of approximately $3 \mathrm{~cm}$ (red and white). In addition, attributes such as sumping in the right-left ear, epolet whose position is above the shoulders with a tassel made of silver threads, sampur (dancing scarf) to hold the dhodhog, and long socks equipped with jingle on the foot wrist.

Development and renewal occur in the fashion or costumes of this art. Those are increasingly visible color, from a black background to brighter colors. Also, yellow, green, red, blue, even batik motifs are used as the basic color of the costume.
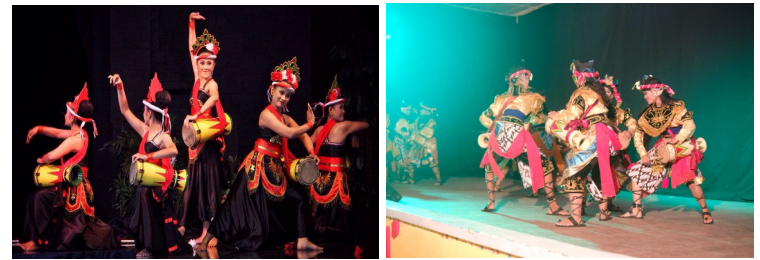

Figure 1 Reog Kendang Dancers

The Reog Kendang was often used to be performed on fields, arena stage, home yards, even roads, and played during the day. After renewal and demands of the performance artworld, it also developed. It is not only staged on the field or arena but also staged in door and on proscenium stage. Since room lighting is usually limited, the lighting system is needed and adjusted based on the needs expected in the show.

When the event is held in door, lighting is very necessary to illuminate the dancers on the stage to make the audience enjoy the show. It is adjusted to the intended needs, namely the use of general illumination and the specification of illumination set in such a way as to add to the aesthetics of the performance. Thus, Reog Kendang can be enjoyed by the community at any time. With these developments the art has often been staged in prestigious events even as the representatives of East Java Province in major regional events.

Postmodernism viewed by artists who have creative, innovative, and new ideas that emerge to create a creativity for the Reog Kendang Art is able to make a Tulungagung distinctive art known by the wider and national community.

\section{CONCLUSION}

Kendang Reog art in Tulungagung Regency is a popular dance composition depicting the procession of Kedhirilaya troop while accompanying Princess Kilisuci in a jurney to Mount Kelud to witness the results of Jathasura's work regarding the conditions She provided. The art is played by 6 dancers in a Reog Kendang unit.
The existence of this art has been increasingly recognized by the public since experiencing the development and renewal since 2018 and 2019, and even now the Reog Kendang art has undergone changes and improvements to beautify the presentation form by organizing motion, accompaniment, floor design, cosmetology, make up, lighting, and venue. The development of the Reog Kendang performance can be felt because the original presentation of the monotonous accompaniment becomes more dynamic; the movements are more creative and attractive; the floor design

\section{REFERENCES}

[1] Tamansiswa, Majelis Luhur. "Karya Ki Hadjar Dewantara, Bagian Kedua Kebudayaan [Ki Hadjar Dewantara's Work, Second Chapter: Cultures]." (2011).

[2] Endin. Reyog Tulungagung Kesenian Tradisional Khas [Reyog Tulungagung Traditional Arts]. Tulungagung: Dinas Kebudayaan Pariwisata Pemuda dan Olahraga Kabupaten Tulungagung. Bidang Kebuyaan, 2008.

[3] Endraswara, Suwardi. Metodologi Penelitian Postmodernisme Sastra [Research Methodology of Literary Postmodernism]. Yogyakarta: CAPS, 2016.

[4] Setiawan, Johan, and Ajat Sudrajat. "Pemikiran Postmodernisme dan Pandangannya terhadap Ilmu Pengetahuan [Postmodernism's Thoughts and Views on Science].” Gadjah Mada University, 2018.

[5] Koentjaraningrat. Kesenian Tradisional [Traditional Arts]. Jakarta: Surya Pena, 1990.

[6] Lyotard, Jean-François. The postmodern condition: A report on knowledge. Vol. 10. U of Minnesota Press, 1984.

[7] Maulana, Achmad. "Kamus Ilmiah Populer [Popular Scientific Dictionary]." Penerbit Absolut, Yokyakarta (2004).

[8] Maksum, Ali. "Pengantar Filsafat: Dari Masa Klasik Hingga Postmodern [Introduction to Philosophy: From Classical to Postmodern Era]." (2014).

[9] Miles, B.M \& A.M Huberman. Analisis Data Kualitatif [Qualitative Data Analysis] .Jakarta, Indonesia: UI Press. 2009.

[10] Soedarsono. Perkembangan Seni Tradisi [The Development of Traditional Art]. Yogyakarta: Ikalasti. 1999.

[11] Suharsaputra, Uhar. "Metode penelitian kuantitatif, kualitatif, dan tindakan [Quantitative, Qualitative, and 
Action Research Methods]." Bandung: PT Refika Aditama (2012).

[12] Syaodih, Nana. "Sukmadinata, Metode Penelitian Pendidikan [Sukmadinata, Educational Research Methods].'Bandung: PT." Remaja Rosdakarya (2009).

[13] Jakob, Sumardjo. "Filsafat seni [Philosophy of art]". Bandung: Penerbit ITB (2000)

[14] FN Apriani, S Sutiyono. "Makna Simbolis Ragam Gerak Tari Jathil Obyog Masal 95-Nan Dalam

Kesenian Reyog Obyog Di Desa Pulung, Kabupaten Ponorogo [The Symbolic Meaning of Jathil Obyog 95Nan Mass Dance Movements in Reyog Obyog Art in Pulung Village, Ponorogo Regency]. " Imaji: Jurnal Seni dan Pendidikan Seni, 2018. 16 (1), 1-8.

DOI: https://doi.org/10.21831/imaji.v16i1.22266 